\title{
jurnal \\ Pengaruh Desinfeksi Energi Microwave Terhadap Kekuatan Transversal Resin Akrilik Polimerisasi Panas
} material kedokteran gigi

p-ISSN 2302-5271

e-ISSN 2685-0214

\author{
Sefty Aryani Harahap, Lasminda Syafiar, Yosepha \\ Yulinda Esdaria Lubis \\ Departemen Ilmu Material Kedokteran Gigi \\ Fakultas Kedokteran Gigi Universitas Sumatera Utara \\ Medan, Indonesia
}

DOI 10.32793/jmkg.v8i1.363

\begin{abstract}
ABSTRAK
Desinfeksi dengan energi microwave sangat disarankan sebagai solusi permasalahan desinfeksi secara kimia pada basis gigi tiruan. Bahan yang sering digunakan sebagai basis gigi tiruan adalah resin akrilik polimerisasi panas. Tujuan penelitian untuk mengetahui pengaruh desinfeksi resin akrilik polimerisasi panas dengan energi microwave terhadap kekuatan transversal pada waktu yang berbeda. Spesimen sebanyak 30 plat $(n=6)$ resin akrilik polimerisasi panas dengan ukuran $65 \times 10 \times 2,5 \mathrm{~mm}$ dibagi menjadi 5 kelompok (kontrol, dan desinfeksi dengan microwave selama 2, 4, 6, dan 8 menit dengan daya 650 Watt). Uji kekuatan transversal dilakukan menggunakan Torsee's Electronic System Universal Testing Machine dengan kecepatan uji 0,1 mm/detik, dan beban 50 kgf. Analisis data menggunakan ANOVA satu arah dan pos hoc LSD. Terdapat perbedaan kekuatan transversal yang signifikan antarkelompok $(p<0,05)$. Nilai rerata kekuatan transversal tiap kelompok (kontrol (tidak didesinfeksi, desinfeksi 2, 4, 6, dan 8 menit), berturut-turut sebagai berikut 103,59 $\pm 0,66 \mathrm{MPa}$; $112,02 \pm 2,10 \mathrm{MPa} ; 117,48 \pm 1,73 \mathrm{MPa} ; 125,46 \pm 2,25 \mathrm{MPa}$; dan $135,89 \pm 1,56 \mathrm{MPa}$. Kesimpulan, Semakin lama didesinfeksi dengan energi microwave, semakin tinggi kekuatan transversal resin akrilik polimerisasi panas.
\end{abstract}

Kata kunci: desinfeksi energi microwave, resin akrilik polimerisasi panas, kekuatan transversal.

\section{The Effect Of Disinfectant By Microwave Energy On The Transversal Strength Of Heat Cured Acrylic Resin}

\section{ABSTRACT}

Disinfectant by microwave energy is highly recommended as a solution to solve the problem of chemical disinfection on denture bases. One of the denture base materials is heat cured acrylic resin. Aim, to evaluate the effect of disinfectant by microwave energy with different time on the transversal strength of heat cured acrylic resin. 30 plates $(n=6)$ of heat cured acrylic resin with size $65 \times 10 \times 2,5 \mathrm{~mm}$ were divided into 5 groups (control; and microwave energy disinfected for 2, 4, 6, and 8 minutes 
with 650 Watts of power). Transversal strength test was carried out using Torsee's Electronic System Universal Testing Machine with a test speed of $0.1 \mathrm{~mm} / \mathrm{second}$, and a load cell of $50 \mathrm{kgf}$. Data analyzed using oneway ANOVA and LSD pos hoc. Results, there were significant differences in the transverse strength among all groups ( $p<0.05)$. Mean values of all groups were $103.59 \pm 0.66$ $\mathrm{MPa} ; 112.02 \pm 2.10 \mathrm{MPa} ; 117.48 \pm 1.73$ $\mathrm{MPa} ; 125.46 \pm 2.25 \mathrm{MPa}$; and $135.89 \pm 1.56$ MPa respectively. Conclusion, the longer it is disinfected by microwave energy, the higher the transversal strength of heat cured acrylic resin.

Keywords: microwave energy disinfection, heat cured acrylic resin, transversal strength.

\section{PENDAHULUAN}

Resin akrilik telah digunakan sebagai basis gigitiruan selama lebih dari 70 tahun dan saat ini merupakan bahan yang paling umum digunakan untuk pembuatan basis gigitiruan, hal ini disebabkan karena bahan tersebut mudah didapat, teknik aplikasi yang relative sederhana, hasil estetik yang memuaskan dan mudah untuk diperbaiki. ${ }^{1-5}$ Secara kimia, desinfeksi gigitiruan dianjurkan menggunakan larutan glutaraldehid, sodium hipoklorit, iodoform, klorin dioksida, khlorheksidin 4\%, dan alkohol.6-9 Namun penggunaan desinfeksi ini memiliki kerugian karena berpengaruh secara signifikan terhadap kekerasan, kekuatan fleksural dan stabilitas warna pada gigitiruan dan reaksi jaringan mulut pasien. $6,8,10$

Belakangan ini, desinfeksi dengan energi microwave telah sangat disarankan untuk mengatasi masalah yang berhubungan dengan desinfeksi secara kimia dan banyak digunakan untuk material laboratorium mikrobiologi, peralatan kedokteran gigi, pemakaian yang terkontaminasi kandida dan desinfeksi basis gigitiruan. ${ }^{6,8,10}$ Penggunaan energi microwave lebih dipertimbangkan untuk desinfeksi gigitiruan dibandingkan desinfeksi dengan bahan larutan kimia karena dapat membunuh beberapa mikroorganisme, waktu desinfeksi lebih singkat, dapat mencegah denture stomatitis, tidak memerlukan penyimpanan khusus, tidak mengubah warna atau bau, dan tidak menimbulkan reaksi alergi.7,8,11-13 Konsep yang penting dalam proses penggunaan microwave adalah bahwa pemanasan microwave merupakan konversi energi, bukan pemanasan seperti pada oven konvensional. ${ }^{8}$

Pada penelitian terdahulu dinyatakan bahwa sterilisasi gigitiruan terhadap C.albican dan Streptococcus gordonii dapat dilakukan selama 2, 4, 6, 8 dan 10 menit dengan daya 650 Watt menggunakan microwave rumah tangga yang belum dimodifikasi. ${ }^{12}$ Penelitian yang berbeda mengemukakan bahwa desinfeksi menggunakan microwave selama 3 menit pada 650 Watt dapat mensterilisasikan bahan yang terkontaminasi dengan C.albican, Pseudomonas aeroginosa, Bacillus subtilis dan Staphylococcus aureus, ${ }^{14}$ sedangkan sterilisasi gigitiruan akrilik dengan menggunakan microwave disertai dengan perendaman dengan air selama 3 menit pada 650 Watt dapat membersihkan segala jenis Candida. ${ }^{15}$

Kekuatan transversal adalah salah satu sifat mekanik penting yang harus dimiliki basis gigitiruan untuk dapat bertahan agar tidak patah disebabkan beban pengunyahan yang besar. ${ }^{16}$ Adapun tujuan penelitian ini adalah untuk mengetahui mengetahui pengaruh desinfeksi resin akrilik polimerisasi panas dengan energi microwave terhadap kekuatan transversal pada waktu yang berbeda.

\section{BAHAN DAN METODE}

Spesimen resin akrilik polimerisasi panas sebanyak 30 plat $(n=6)$ dengan ukuran $65 \times 10 \times 2,5 \mathrm{~mm}$ sesuai dengan standar dari ADA specification No. 12, 8,13,161818 yang dibagi menjadi 5 kelompok, yaitu A: kontrol (tidak didesinfeksi); B: desinfeksi dengan microwave selama 2 menit; C: desinfeksi dengan microwave selama 4 menit; $D$ : desinfeksi dengan microwave selama 6 menit; dan E: desinfeksi dengan microwave selama 8 menit. Desinfeksi dengan microwave menggunakan daya 650 
Watt.

Proses curing dilakukan menggunakan waterbath dimulai pada suhu kamar dan dinaikkan terus hingga suhu $740 \mathrm{C}$, lalu dipertahankan selama 1,5 jam, kemudian suhu dinaikkan menjadi $1000 \mathrm{C}$ dan dipertahankan selama 1 jam, setelah itu suhu pelan-pelan diturunkan hingga sama dengan suhu ruangan. ${ }^{18}$ Lalu penyelesaian akhir dan pemolesan dilakukan untuk mendapatkan spesimen resin akrilik polimerisasi panas dengan kontur yang rata, licin, mengkilat dan tidak poreus. ${ }^{18}$

Desinfeksi spesimen dilakukan pada masing-masing kelompok B, C, D, dan E. Pada kelompok $B$, spesimen dimasukkan dalam gelas beker berisi $200 \mathrm{ml}$ air, lalu dimasukkan ke dalam microwave selama 2 menit dengan daya 650 Watt. Setelah itu, gelas beker dikeluarkan dari microwave, dan termometer dimasukkan ke dalam gelas beker untuk mengetahui suhu dari daya 650 Watt. Suhu yang terlihat adalah $880 \mathrm{C}$ dan suhu yang telah diukur kemudian dicatat. Termometer dibiarkan didalam gelas beker untuk dilihat suhunya, lalu gelas beker dibiarkan dingin sampai mencapai suhu kamar. Kemudian dilakukan pengujian kekuatan transversal spesimen. Hal yang sama dilakukan pada kelompok C, D, dan E. Suhu yang terlihat pada tersebut adalah $910 \mathrm{C}$ dan suhu yang telah diukur kemudian dicatat. Pada kelompok $A$ dilakukan pengujian kekuatan transversal tanpa desinfeksi terlebih dahulu.

Uji kekuatan transversal dilakukan menggunakan Torsee's Electronic System Universal Testing Machine(2tf 'Senstar', SC -2-DE, Tokyo-Japan) dengan kecepatan uji $0,1 \mathrm{~mm} /$ detik, dan beban $50 \mathrm{kgf}$. Jarak antara kedua penyangga adalah $50 \mathrm{~mm}$. Kekuatan transversal ditentukan melalui rumus :8,16,1

$$
\frac{3 \mathrm{Pl}}{\mathrm{S}=2 \mathrm{bdxd}}
$$

Di mana, $\mathrm{S}=$ Kekuatan transversal $(\mathrm{MPa})$; $\mathrm{L}=$ Jarak pendukung $(\mathrm{mm}) ; \mathrm{P}=$ Beban $(\mathrm{kgF}) ; \mathrm{b}=$ Lebar batang uji $(\mathrm{mm}) ; \mathrm{d}=$ Tebal bantang uji ( $\mathrm{mm})$.

Analisis data menggunakan one way ANOVA dan pos hoc LSD ( $p \leq 0.05)$.

\section{HASIL}

Pada penelitian ini terlihat bahwa nilai rata-rata kekuatan transversal resin akrilik polimerisasi panas setelah didesinfeksi dengan energi microwave pada waktu berbeda ( 2 menit, 4 menit, 6 menit, dan 8 menit) mengalami penambahan kekuatan transversal seiring dengan bertambahnya waktu desinfeksi dan bila dibandingkan dengan nilai rata-rata kekuatan transversal resin akrilik polimerisasi panas yang dijadikan sebagai kelompok kontrol.(Tabel 1)

Tabel 1. Nilai rerata dan standar deviasi kekuatan transversal resin akrilik polimerisasi panas yang didesinfeksi dengan energi microwave pada waktu yang berbeda

\begin{tabular}{|cc|}
\hline Kelompok & Kekuatan Tranversal (MPa) \\
\hline A (Kontrol) & $103,59 \pm 0,66$ \\
B (2 Menit) & $112,02 \pm 2,10$ \\
C (4 Menit) & $117,48 \pm 1,73$ \\
D (6 Menit) & $125,46 \pm 2,25$ \\
F (8 Menit) & $135,89 \pm 1,56$ \\
\hline
\end{tabular}

Tabel 2. Perbandingan kekuatan transversal resin akrilik polimerisasi panas antarkelompok waktu yang berbeda

\begin{tabular}{|ccc|}
\hline Kelompok & & Sig \\
\hline A (Kontrol) & A & $.00 *^{*}$ \\
& B & $.000^{*}$ \\
& C & $.000^{*}$ \\
& D & $.00 *^{*}$ \\
& E & $.000^{*}$ \\
\hline B (2 Menit) & C & $.00 *^{*}$ \\
& D & $.000^{*}$ \\
& E & $.000^{*}$ \\
\hline C (4 Menit) & D & $.000^{*}$ \\
& E & $.000^{*}$ \\
\hline D (6 Menit) & E & $.000^{*}$ \\
\hline
\end{tabular}

*Signifikan pada $\mathrm{P}<0.05$,

Pada tabel 2 diperoleh nilai $\mathrm{p}<0.05$, hal ini menunjukkan bahwa terdapat perbedaan yang signifikan dari kekuatan 
transversal resin akrilik polimerisasi panas antarkelompok.

\section{PEMBAHASAN}

Berdasarkan hasil penelitian ini terlihat bahwa terdapat perbedaan signifikan kekuatan transversal resin akrilik polimerisasi panas antara kelompok A (kontrol), kelompok B (desinfeksi selama 2 menit), kelompok C (desinfeksi selama 4 menit), kelompok D (desinfeksi selama 6 menit), dan kelompok E (desinfeksi selama 8 menit). Penelitian ini sesuai dengan penelitian Al-Saraj dkk yang menyatakan bahwa kekuatan transversal resin akrilik polimerisasi panas setelah desinfeksi dengan microwave disertai dengan air didalamnya mengalami pertambahan kekuatan transversal secara signifikan dengan lama desinfeksi 3 menit dan hanya dengan daya 540 Watt bila dibandingkan dengan resin akrilik polimerisasi panas yang tidak didesinfeksi dengan energi microwave. Hal ini disebabkan monomer sisa yang dihasilkan oleh resin akrilik polimerisasi panas setelah dilakukan desinfeksi telah terkonversi menjadi polimer, sehingga tidak ada lagi monomer sisa. Apabila kandungan monomer sisa tinggi, kekuatan antar rantai polimer menurun. Hal ini dapat dijelaskan dengan adanya peningkatan kekuatan transversal yang disebabkan oleh panas ketika dilakukan desinfeksi dengan energi microwave, telah membuat molekul monomer yang tidak bereaksi berdifusi ke permukaan dan menguap. ${ }^{16}$

Menurut penelitian Suvarna dkk, energi microwave hanya berperan pada monomer, yaitu berkurangnya monomer sisa seiring dengan bertambahnya derajat polimerisasi. Didalam microwave, molekul monomer bergerak dengan medan elektromagnetik frekuensi tinggi, pergerakan molekul monomer tersebut disebabkan karena terjadinya panas internal.19 Kekuatan transversal resin akrilik dipengaruhi oleh berbagai faktor seperti berat molekul, ukuran partikel polimer, monomer sisa, komposisi plasticizer, jumlah ikatan silang pada rantai molekul, porositas, dan ketebalan basis gigitiruan. ${ }^{18,20}$
Penelitian Konchada dkk menyatakan bahwa tidak ada perbedaan kekuatan transversal, kekuatan impak dan kekerasan yang signifikan antara kelompok yang tidak didesinfeksi dengan energi microwave dan yang didesinfeksi dengan energi microwave selama 5 menit dengan daya 650 Watt. Hal ini mungkin disebabkan oleh perbedaan jenis dan merk resin akrilik. Oleh karena tidak adanya perubahan kekuatan transversal, kekuatan impak dan kekerasan pada resin akrilik setelah didesinfeksi dengan energi microwave, Koncahada dkk menyimpulkan bahwa metode desinfeksi menggunakan energi microwave bisa efektif digunakan dalam mengeleminasi patogen mikrobial. ${ }^{6}$

\section{SIMPULAN}

Semakin lama resin akrilik polimerisasi panas didesinfeksi dengan energi microwave, kekuatan transversal semakin meningkat.

\section{DAFTAR PUSTAKA}

1. AL-Bahar ZJH. Evaluation the effect of incorporated hydroxyapatite prepared from dried egg shell on some properties of relined denture base. International Science Basic and Applied Research 2014; 5: 13, 20-5, 45-6.

2. Anusavice KJ. Dental materials. 11th ed. Hong Kong: Saunders Elsevier, 2007: 143-69, 721-59.

3. Almashhadany HKM. The effect of newly prepared cleansing agent on some properties of higgly impact acrylic denture base material. Thesis: Washington DC: ORIC Publications, 2014: 4-6.

4. Van Noort R. Introduction to dental materials. 2nd. London: Mosby Inc.,2002: 211-20.

5. 5. Amin F, Iqbal S, Azizuddin S, Afridi FI. Effect of denture cleansers on the color stability of heat cure acrylic resin. Journal of the College of Phisicians and Surgeons Pakistan 2014; 24: 787.

6. Konchada J, Khartigeyan S, Ali SA, Venkateshwaran $R$, Amirisetty $R$, Dani A. Effect of simulated microwave 
disinfection on the mechanical properties of three different types of denture base resins. Journal of Clinical and Diagnostic Research 2013; 7(12): 3051-3.

7. Consani RLX, Vieira EB, Mesquita MF, Mendes WB, Arioli-filho JN. Effect of microwave disinfectionon physical and mechanical properties of acrylic resin. Braz Dent J 2008; 19(4): 348-53.

8. Hamouda IM, Ahmed SA. Effect of microwave disinfection on mechanical properties of denture base acrylic resin. Journal of Mechanical Behavior of Biomedical Materials 2010; 3: 480-7.

9. Nallaswamy D. Textbook of prosthodontics. 1st ed. New Delhi: Jaypee Brothers Medical Publishers (P) Ltd, 2003: 4-6, 210-7.

10. Silva MM, Vergani CE, Giampaolo ET, Neppelenbroek KH, Spolidorio DMP, Machado AL. Effectiveness of microwave irradiation on the disinfection of complete denture. The International Journal of Prosthodontic 2006; 19(3): 288-93.

11. Karibasappa GN, Sujatha A, Singh R, Prithiani P, Rajeshwari K. Microwave - a novel wave in dentistry. Journal of Dental and Medical Sciences 2013; 12(3): 1-5.

12. Vergani CE, Ribeiro DC, Dovigo LN, Sanita PV, Pavarina AC. Microwave assisted disinfection method in dentistry, microwave heating. 2011; 21(1): 63-78.

13. Ali AM, Raghdaa KJ. Evaluation and comparison of the effect of repeated microwave irradiations on some mechanical and physical properties of heat cure acrylic resin and valpast (nylon) denture base materials. J Bagh College Dentistry 2011; 23(3): 6-10.

14. Silva MM, Mima EGO, Colombo AL, Sanita PV, Jorge JH, Massucato EMS et al. Comparison of denture microwave disinfection and conventional antifungal therapy in the treatment of denture stomatitis: a randomized clinical study. Oral Surg Oral Med Oral Pathol Oral Radiol 2012; 114(4): 469-79.

15. Dantas APFM, Consani RLX, Sardi JCO, Mesquita MF, Silva MCVS, Sinhoreti MAC, Biofilm formation in denture base acrylic resins and disinfection method using microwave. Journal of Research and Practice in Dentistry 2014; 2014: 1-9.

16. Al-Saraj A, Kazanji MN, Rahman GYA. Effect of microwave disinfection on transverse strength and hardness of acrylic resin denture base materials. AlRafidain Dent J 2011; 11(2): 284-91.

17. Al-Taie Ghassan A, Khamas AHM. Comparison of transverse strength of repaired visible light-polymerized resin to pressured auto polymerizing and conventional heat-polymerized acrylic resin. J Bagh College Dentistry 209; 21(4): 30-2.

18. Powers JM, Craig RG. Restorative dental material. 11th ed. Missouri: Mosby Inc., 2002: 476-7, 636-54

19. Suvarna S, Chhabra T, Raghav D, Singh D, Kumar P, Sahoo S. Residual monomer content of repair autopolumerizing resin after microwave postpolymerization treatment, European Journal of Prosthodontics 2014; 2(1): 28-32.

20. McCabe JF, Walls AWG. Applied dental materials. 9th ed. Singapore: Blackwell Munksgaard, 2008: 110-20. 